\title{
Editorial
}

\section{Faculty Status for Librarians: Force-Fitting into an Inappropriate Mold or Not?}

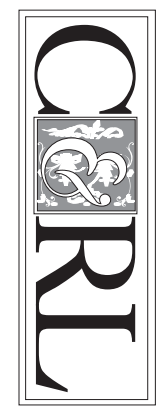

Much has been written on the status of academic librarians. If one were to compile a bibliography on the topic, it would be reasonable to expect at least 250 entries. Based on a casual observation of the literature, many of the articles published on the topic occurred in the 1970s and 1980s. Fewer articles have been published on the status of academic librarians in the 1990s than in the 1980s. Are our colleagues having second thoughts about achieving and/ or maintaining faculty status? I think not. Notwithstanding the tremendous growing pressures on academic librarians to meet higher expectations of users, it is my opinion that most librarians with faculty status still firmly believe in the virtues associated with this standing.

\section{Due to the position (chief officer of the university libraries), provosts and presidents normally "give" the head librarian the rank of professor or its equivalent.}

\section{Personal Bias}

Unquestionably, I believe in and support faculty status for librarians. My professional career has provided me the opportunity to work in libraries with faculty status and rank, in libraries with only faculty status, and in libraries without either. Librarians with faculty status and rank (i.e., assistant professor, associate professor, professor) tend to be better perceived as peers by nonlibrarian faculty. Also, these librarians appear to have more intellectual vibrancy, owing, Ibelieve, to the research and publishing expectations. Nevertheless, if a library does not have faculty status and the librarians do not want to pursue such, I believe it is counterproductive to force faculty status on them. Faculty status carries with it many expectations and responsibilities.

Job performance is usually the criterion given the most weight during evaluations of academic librarians. However, research/ publications is the number one criterion for promotion/tenure for teaching faculty in many research universities. At some major research universities, excellent teaching may be suspect (i.e., devoting too much time to teaching and not enough time to research). The "teacher of the year" recipients at some universities have lost their jobs because they did not have sufficient publications to qualify for tenure.

\section{Do as I Say}

Unlike the deans of schools and colleges in major research universities, many of the directors of libraries holding membership in the Association of Research Libraries do not hold a doctorate and are not perceived as established scholars. They are generally perceived as good administrators. Search committees (which normally include some nonlibrarian faculty) are recommending librarians to fill the position of director/university librarian/dean whose research/publications may only qualify them for the rank of assistant professor. However, due to the position (chief officer of the university libraries), provosts and presidents normally "give" the head librarian the rank of professor or its equivalent. And this same head librarian has final say on the 
promotion of librarians jumping the hurdles necessary for becoming an associate professor and professor. Four-year colleges and small- to medium-sized universities tend to place more emphasis on the doctorate while filling their head librarian position. Could one extract from these practices that research universities are less interested in their head librarians having an understanding of research skills (e.g., completion of a doctoral dissertation) than four-year colleges and small- to medium-sized universities? Possibly. Such practices contain a bit of both irony and paradox.

\section{Why Bother?}

Librarians have expressed to me their earnest concerns about faculty status. Some believe faculty status has a negative impact on their service performance. Many are concerned about lacking the skills necessary to perform research at a level comparable to the nonlibrarian faculty. In addition, the length of appointment (i.e., nineor ten-month versus twelve-month) is an understandable bone of contention for librarians. Why should the nonlibrarian faculty get two to three months off in the summer to conduct research, recharge, and reflect while librarians have twelve-month appointments? In 1983, John N. DePew expressed his views on problems generated by faculty status for librarians:

Faculty status is inappropriate for librarians because it creates tensions that obscure the proper role of the librarian, and it interferes with the effective delivery of library services by diverting librarians' energies and attentions from those services. ${ }^{1}$

\section{The Debate Continues}

The ACRL Academic Status Committee has been quite active in strengthening the concept and practice of granting/maintaining academic status for librarians. This important committee has expressed concern that with each succeeding generation of librarians, there is a worry that the values of academic status are being forgotten. ${ }^{2}$ According to the Academic Status Committee, guarantees of academic freedom, provision of collegial governance, fair compensation, greater involvement in and support for the educational process, higher standards of achievement for librarians, and recognition of librarians' teaching role are some of the basic reasons that faculty status should endure and flourish. ${ }^{3}$

In 1993, Beth J. Shapiro argued that there are many myths about faculty status for librarians. She indicated that ACRL should reevaluate faculty status for librarians because the concept has outlived its usefulness and that ACRL should stop promoting unproductive issues such as faculty status and begin developing a framework for professional work in the library of the twenty-first century. ${ }^{4}$

In the graduate library and information science courses I teach, the issue of faculty status surfaces. My advice to the students planning to become academic librarians is that if they want to become like the nonlibrarian faculty, they should seek employment in an institution of higher education offering faculty status for librarians. If they do not want the responsibilities that go with faculty status, they should look for employment in an academic setting that does not require such. Regardless, the decision is personal and should be respected. And that is the way it should be!

DONALD E. RIGGS Editor

\section{Notes}

1. Thomas N. DePew, "The ACRL Standards for Faculty Status: Panacea or Placebo," College \& Research Libraries 44 (Nov. 1983): 407-13.

2. "Faculty Status: 2001," College \& Research Libraries News 54 (June 1993): 338-40.

3. Ibid., 339.

4. Beth J. Shapiro, "The Myths Surrounding Faculty Status for Librarians," College \& Research Libraries News 54 (Nov. 1993): 362-63. 